\title{
Syphilis; consequences and implications in delayed diagnosis. Five cases of secondary syphilis presenting with ocular symptoms.
}

\author{
Muldoon, Eavan $\mathrm{G}^{1}$. Hogan, Aideen². Kilmartin, Dara ${ }^{2}$. McNally, Cora ${ }^{1}$. \\ Bergin, Colm ${ }^{1,3}$. \\ ${ }^{1}$ Department of Genitourinary Medicine and Infectious Diseases, St. James's Hospital, \\ Dublin, Ireland. ${ }^{2}$ Department of Ophthalmology, Royal Victoria Eye and Ear Hospital, Dublin, \\ Ireland. ${ }^{3}$ Trinity College Dublin, Ireland. \\ Corresponding Author \\ Eavan Muldoon \\ Department of Genitourinary Medicine and Infectious Diseases, St James's Hospital, Dublin 8, Ireland \\ ph; 353-86-3855145 \\ email eavan@esatclear.ie \\ no fax available
}

\section{Authors Contribution}

E Muldoon- Medical care of patients and summary of cases and article text

A Hogan- Ophthalmology care of patients and summary of ophthalmic presentation and findings

D Kilmartin- Opthalmology care of patients and summary of ophthalmic presentation and findings

C McNally-Medical care of patients and summary of cases

C Bergin- Medical care of patients and review of article prior to submission

\section{Key Messages}

- Syphilis should be considered as an important treatable cause of uveitis. Untreated it could lead to irreversible vision loss.

- Careful history may give clues to diagnosis; systemic symptoms are common prior to the onset of ocular syphilis.

- HIV negative patients also present with ocular syphilis.

- Sexual health history should be incorporated into the evaluation of all patients.

Key Words

Syphilis, T. pallidum, ophthalmic, ocular, MSM

Competing interests: none declared

Word count 745 . 


\section{Abstract}

Ocular manifestations of syphilis are uncommon ${ }^{1}$. We present five cases of ocular syphilis four of whom had a delay in their diagnosis. Four of the patients were men who have sex with men (MSM) and four patients were human immunodeficiency virus (HIV) negative.

\section{Introduction}

A large outbreak of syphilis was first described in Dublin in $2001^{2}$ The incidence of infection decreased until 2007 when a further increase was reported ${ }^{3}$. Ocular manifestations of syphilis are uncommon. We present five cases diagnosed with ocular syphilis four of whom had a delay in their diagnosis. These patients presented over an eight-month period during which 118 diagnoses of early infectious syphilis were made in our centre. Four of the patients were men who have sex with men (MSM). Four patients were human immunodeficiency virus (HIV) negative.

Ocular syphilis has a broad spectrum of presentation. Posterior uveitis, retinal vascular involvement, placoid maculopathy, retinal detachment, involvement of the cornea, episcleritis and scleritis and interstitial keratitis presenting as open angle glaucoma have all been described ${ }^{4,5}$. Delay in the diagnosis of ocular syphilis can lead to irreversible visual loss due to optic nerve and retinal atrophy 6 .

\section{Case reports}

All five patients presented with decreased visual acuity. All patients were male, mean age 44.2 years (range 40-50) and four identified MSM as a risk for syphilis infection. Patient characteristics are outlined in table 1. All of the patients described systemic symptoms prior to onset of visual symptoms (table 1). One patient was known HIV positive; CD4 398 cells $/ \mathrm{mm}^{3}$, virally suppressed on antiretroviral therapy. Three of five patients underwent lumbar puncture; all had a CSF pleocytosis. All patients received parenteral penicillin (either procaine penicillin and probenecid or benzylpenicillin for 14 days).

All of the HIV negative patients had a delay in the diagnosis of their syphilis. The time from onset of ocular symptoms to diagnosis ranged from six weeks to four months. The HIV positive patient had no delay in diagnosis. Three HIV negative patients attended for repeat HIV testing, all remained seronegative.

\begin{tabular}{|l|l|l|l|l|l|l|l|}
\hline Pt & Risk & $\begin{array}{l}\text { Preceding } \\
\text { symptoms }\end{array}$ & $\begin{array}{l}\text { Ophthalmic } \\
\text { findings }\end{array}$ & $\begin{array}{l}\text { Steroid } \\
\text { therapy } \\
\star \star\end{array}$ & RPR $^{\star}$ & $\begin{array}{l}\text { RPR } \\
\mathbf{3} \\
\text { mth }\end{array}$ & $\begin{array}{l}\text { Response } \\
\text { to therapy }\end{array}$ \\
\hline 1 & MSM & $\begin{array}{l}\text { Malaise, fever, } \\
\text { lymphadenopathy } \\
\text { \& alopecia. }\end{array}$ & $\begin{array}{l}\text { Neuroretinitis \& } \\
\text { choroiditis }\end{array}$ & Yes & $1: 256$ & $1: 16$ & $\begin{array}{l}\text { Full } \\
\text { resolution } \\
\text { of } \\
\text { symptoms }\end{array}$ \\
\hline 2 & MSM & $\begin{array}{l}\text { Rash \& general } \\
\text { malaise. }\end{array}$ & $\begin{array}{l}\text { Extensive } \\
\text { chorioretinitis \& } \\
\text { disc oedema }\end{array}$ & No & $1: 512$ & $1: 8$ & $\begin{array}{l}\text { Full } \\
\text { resolution } \\
\text { of } \\
\text { symptoms }\end{array}$ \\
\hline 3 & MSM & Rash. & $\begin{array}{l}\text { Dense vitritis \& } \\
\text { choroiditis. }\end{array}$ & Yes & $1: 128$ & $1: 8$ & $\begin{array}{l}\text { Severe } \\
\text { visual }\end{array}$ \\
\hline
\end{tabular}




\begin{tabular}{|l|l|l|l|l|l|l|l|}
\hline 4 & MSM & Fatigue. & $\begin{array}{l}\text { Neuroretinitis \& } \\
\text { choroiditis }\end{array}$ & No & $1: 128$ & $1: 16$ & $\begin{array}{l}\text { Full } \\
\text { resolution } \\
\text { of } \\
\text { sypmtoms }\end{array}$ \\
\hline 5 & $\begin{array}{l}\text { Heterosexual } \\
\text { unprotected } \\
\text { intercourse }\end{array}$ & $\begin{array}{l}\text { Inguinal } \\
\text { lymphadenopathy }\end{array}$ & $\begin{array}{l}\text { Anterior uveitis, } \\
\text { vitritis \& focal } \\
\text { retinitis. }\end{array}$ & Yes & $1: 128$ & $1: 4$ & $\begin{array}{l}\text { Full } \\
\text { resolution } \\
\text { of } \\
\text { symptoms }\end{array}$ \\
\hline
\end{tabular}

Table 1- Characteristics of patients presenting with ocular syphilis.

* All non-treponemal tests were confirmed with $T$. pallidum particle agglutination (TPPA)

${ }^{\star \star}$ Steroid therapy refers to steroids commenced prior to antibiotic therapy

\section{Discussion}

Ocular manifestations of sexually acquired syphilis can occur at any stage of disease. The presentation of ocular involvement is varied, however the most common presentation of syphilis in the eye is uveitis. This can occur as early as six weeks after primary infection. When uveitis occurs in secondary syphilis it often follows the resolution of other signs and symptoms. The most common manifestations in patients with uveitis who presented to a New York clinic over a five-year period were granulomatous iridiocyclitis, non-granulomatous iridiocyclitis, panuveitis, posterior uveitis and keratouveitis ${ }^{7}$. Anterior segment inflammation may be associated with a vitritis. Posterior uveitis is most commonly manifested as a chorioretinitis. As the clinical manifestations of syphilitic uveitis are non-specific, the work up for patients presenting with an unexplained uveitis should include testing for syphilis.

Sexual history may give a clue to the possible aetiology of a patient's uveitis, four of our patients were MSM and all reported episodes of unprotected sexual intercourse in the months preceding the onset of symptoms. These details were not elicited at initial presentation. Ocular involvement may be more severe in patients with HIV co-infection and is related to immune status ${ }^{8}$. Syphilis is now more common than cytomegalovirus as a cause of uveitis among patients on anti-retroviral therapy ${ }^{9}$.

As ocular syphilis is a manifestation of neurosyphilis, it should be treated with parenteral penicillin daily for a period of ten to seventeen days. Patients with reported penicillin sensitivity should be desensitized and treated with penicillin. The Jarish-Herxheimer $(\mathrm{JH})$ reaction, a systemic reaction following antibiotic therapy can occur in the treatment of any stage of syphilis but is most common in secondary syphilis. It occurs one to two hours after administration of therapy. There are case reports of significant deterioration in symptoms or serious adverse events secondary to the $\mathrm{JH}$ reaction following therapy ${ }^{10}$. Steroid therapy prior to antibiotic therapy is recommended in patients with ophthalmic syphilis. 
Ocular syphilis can be difficult to diagnose and if left untreated can lead to irreversible visual loss. If not considered during the evaluation of patients presenting with ocular symptoms of unclear aetiology the diagnosis may be missed. Four of our patients had a delay in the diagnosis of ocular syphilis after presenting with ophthalmic symptoms; all were HIV negative. Careful history taking regarding risks factors, history of possible chancrous lesions or systemic illness and or rash prior to the onset of visual symptoms may offer vital clues in making the diagnosis of this treatable disease.

1. Kiss S, Damico FM, Young LH. Ocular manifestations and treatment of syphilis. Semin Ophthalmol 2005;20:161-7.

2. Hopkins S, Lyons F, Mulcahy F et al. The great pretender returns to Dublin, Ireland. Sex Transm Infect 2001;77:316-8.

3. Muldoon EG, Kelleher M, Squance S et al. HIV and Syphilis Co-Infection; Emerging Trends Post Epidemic. In: Conference on Retroviruses and Opportunistic Infections. Montreal, Canada; 2009.

4. Villanueva AV, Sahouri MJ, Ormerod LD et al. Posterior uveitis in patients with positive serology for syphilis. Clin Infect Dis 2000;30:479-85.

5. Parc CE, Chahed S, Patel SV et al. Manifestations and treatment of ocular syphilis during an epidemic in France. Sex Transm Dis 2007;34:553-6.

6. Aldave AJ, King JA, Cunningham ET, Jr. Ocular syphilis. Curr Opin Ophthalmol 2001;12:433-41.

7. Barile GR, Flynn TE. Syphilis exposure in patients with uveitis. Ophthalmology 1997;104:1605-9.

8. Marra CM, Maxwell CL, Smith SL, et al. Cerebrospinal fluid abnormalities in patients with syphilis: association with clinical and laboratory features. J Infect Dis 2004;189:369-76.

9. Gaudio PA. Update on ocular syphilis. Curr Opin Ophthalmol 2006;17:562-6.

10. Pournaras JA, Laffitte E, Guex-Crosier Y. Bilateral giant retinal tear and retinal detachment in a young emmetropic man after Jarish-Herxheimer reaction in ocular syphilis. Klin Monbl Augenheilkd 2006;223:447-9.

"The Corresponding Author has the right to grant on behalf of all authors and $\square$ does grant on behalf of all authors, an exclusive licence (or non exclusive for $\square$ government employees) on a worldwide basis to the BMJ Publishing Group Ltd to $\square$ permit this article (if accepted) to be published in STI and any other BMJPGL $\square$ products and sub-licences such use and exploit all subsidiary rights, as set out $\square$ in our licence $\square$ http://group.bmj.com/products/journals/instructions-forauthors/licence-forms". 